\title{
PENGGUNAAN ANGGARAN PENDAPATAN DAN BELANJA NEGARA (APBN) DALAM PELAKSANAAN PEMILIHAN UMUM ULANG
}

\author{
I Kadek Andika Setiawan, I Gusti Bagus Suryawan, I Wayan Arthanaya \\ Fakultas Hukum, Universitas Warmadewa, Denpasar-Bali, Indonesia \\ andikasetiawan0398@gmail.com, suryawanpetemon@gmail.com, arthanaya.wayan@gmail.com
}

\begin{abstract}
Abstrak
Pelaksanaan pemilihan umum yang mengalami kegagalan akan menimbulkan pemilihan umum ulang dan tentunya membutuhkan anggaran tambahan. Tujuan penelitina ini yaitu untuk mengetahui mekanisme pelaksanaan Pemilihan Umum ulang dan menganalisis penggunaan Anggaran Pendapatan dan Belanja Negara dalam pelaksanaan Pemilihan Umum ulang. Metode penelitian yang digunakan adalah penelitian hukum normative dengan pendekatan perundang-undangan dan juga pendekatan konseptual. Hasil penelitian ini menunjukkan bahwa mekanisme pelaksanaan Pemilihan Umum ulang adalah perselisihan hasil Pemilihan Umum yang disengketakan, oleh calon pasangan Presiden dan anggota calon legislatif melalui putusan Mahkamah Konstitusi. Mekanisme pemberian dana Anggaran Pendapatan dan Belanja Negara dalam pelaksanaan Pemilihan Umum ulang adalah pengajuan anggaran biaya tambahan oleh pihak Komisi Pemilihan Umum kepada Lembaga Anggaran dan Departemen Anggaran untuk merevisi anggaran pelaksanaan Pemilihan umum yang mengalami pelaksanaan Pemilihan Umum ulang.
\end{abstract}

Kata Kunci: Mekanisme, Pemilihan Umum, Pemilu Ulang, APBN

\begin{abstract}
A failed general election will result in a re-election and will certainly require additional budget. The purpose of this research is to find out the mechanism for the implementation of the re-election and to analyze the use of the State Revenue and Expenditure Budget in the implementation of the re-election. The research method used is normative legal research with a statutory approach and a conceptual approach. The results of this study indicate that the mechanism for implementing the re-election is a dispute over the results of the disputed General Election, by presidential candidates and members of the legislative candidates through the Constitutional Court decision. The mechanism for the provision of funds from the State Revenue and Expenditure Budget in the implementation of the re-General Election is the submission of additional costs by the General Election Commission to the Budget Institution and the Budget Department to revise the budget for the implementation of General Elections that are undergoing re-election.
\end{abstract}

Keywords: Mechanism, General Election, Re-election, APBN

\section{PENDAHULUAN}

Negara Indonesia merupakan negara demokrasi. Demokrasi merupakan sistem pemerintahan dari rakyat, oleh rakyat, dan untuk rakyat. Negara demokrasi merupakan negara yang di selenggarakan berdasarkan kehendak dan kekuasaan rakyat sama halnya bahwa rakyat turut serta dalam segala perbuatan pemerintah, atau jika di tinjau dari sudut pandang organisasi ia berarti sebagai suatu pengorganisasian negara yang di lakukan oleh rakyat sendiri atau atas persetujuan rakyat karna kedaulatan rakyat berada di tangan rakyat (MD, 2000).

Dengan mekanisme negara demokrasi pemerintah akan sangat berhati-hati dalam mengambil keputusan yang menyangkut kepentingan rakyat. Kebebasan individu merupakan komponen esensial dari demokrasi. Pengaruh yang dapat diberikan dalam pelaksanaan proses politik yang demokratis dapat memperluas dan memperdalam kebebasan setiap individu. Kebebasan merupakan hal pokok dalam demokrasi. Penerapan dari negara demokrasi adalah dengan adanya Pemilihan Umum. Pemilihan Umum yang demokrasi tergambar dalam Undang-Undang Dasar Negara Republik Indonesia Tahun 1945 Pasal 22E. Dalam pelaksanaan pemilihan umum atas perintah Undang-Undang Dasar dibentuklah Komisi Pemilihan Umum yang selanjutnya disingkat KPU. Dalam kegiatan KPU dalam penyelenggaraan pemilu tidak lepas dari Badan Pengawas Pemilu yang selanjutnya disebut Bawaslu. Pada tahun 2019 negara Indonesia merupakan Negara pertama yang melaksanakan Pemilu serentak memilih anggota legislatife dan eksekutif. Dalam rangka pembangunan nasional, sebagai pengamalan 
pancasila dan UUD NRI 1945, demokrasi atau kerakyatan tidak hanya kita lihat di bidang politik tetapi juga dilihat demokrasi bagi suksesnya pembangunan nasional. Dari bidang ekonomi negara dapat menafsirkan anggaran yang dipergunakan dalam pelaksanaan pemilu yang merupakan pesta demokrasi rakyat.

Dalam Undang-Undang Nomor 17 Tahun 2003 Tentang Keuangan Negara menyatakan, Keuangan negara adalah semua hak dan kewajiban negara yang yang dapat dinilai dengan uang, serta segala sesuatu baik berupa uang maupun berupa barang yang dapat dijadikan milik negara berhubungan dengan pelaksanaan hak dan kewajiban. Dalam penggunaan uang negara harus menggunakan system yang berlaku dan terstruktur.

Dalam rangka penyelenggaraan fungsi pemerintahan untuk mencapai tujuan bernegara mengenai pengelolaan keuangan negara di gunakan Anggaran Pendapatan dan Belanja Negara yang selanjutnya di singkatan APBN yang disusun setiap tahun (Savitri, Dewantara, Darmayanti, Dewi, \& Sari, 2019). APBN terdiri dari anggaran pendapatan, anggaran belanja dan pembiayaan. Pelaksanaan pemungutan suara ulang pasti membutuhkan anggaran tambahan untuk mencetak kembali surat suara untuk di setiap TPS yang dalam pelaksanaan Pemilihan Umum yang gagal mengalami Pemilihan Umum ulang.

Penelitian-penelitian serupa, yaitu penelitian yang mengkaji rumusan yang serupa tetapi dengan hasil yang berbeda salah satunya mengenai analisis keuangan public dalam penyusunan Anggaran Pendapatan dan Belanja Negara Indonesia (APBN) 2018 (Syamsurijal, 2019), lainnya mengenai analisis kinerja anggaran belanja pada komisi pemilihan umum Provinsi Sulawesi Utara tahun 20102014 (Lumapow, 2015), dan terakhir mengenai implementasi kebijakan pengelolaan keuangan komisi pemilihan umum Provinsi Maluku Utara melalui keputusan KPU No. 506/Kpts/KPU/Tahun 2013 (Bachtiar, Areros, \& Wullur, 2013).

Berdasarkan latar belakang masalah di atas, penelitian yang baru ini bertujuan untuk menganalisi mekanisme pelaksanaan Pemilu ulang dan mengetahui mekanisme penggunaan APBN dalam pelaksanaan Pemilu ulang.

\section{METODE PENELITIAN}

Penelitian ini merupakan penelitian hukum normatif yang bertujuan untuk menilai suatu peraturan perundang-undangan dan dilakukan dengan mengadakan penelitian kepustakaan (Fajar \& Dkk, 2010). Pendekatan masalah dalam penelitian ini menggunakan jenis pendekatan perundang-undangan dan konseptual. Jenis pendekatan perundangan-undangan dan konseptual ini digunakan untuk memperoleh deskripsi penggunaan APBN dalam pelaksanaan Pemilu ulang yang diatur di dalam undang-undang. Adapun sumber bahan hukum yang digunakan sebagai berikut.

1. Bahan hukum primer yaitu peraturan Perundang-Undangan yang berkaitan dengan permasalahan yang akan dikaji diantaranya Undang- Undang Nomor 7 Tahun 2017 tentang Pemilihan Umum dan Undang-Undang Nomor 17 Tahun 2003 Tentang Keuangan Negara.

2. Bahan hukum sekunder yaitu bahan hukum yang diperoleh dari buku atau literatur, jurnal hukum, website, artikel-artikel, pendapat para sarjana yang berhubungan dengan permasalahan.

3. Bahan hukum tersier merupakan bahan penunjang ilmu hukum yang dapat memberikan petunjuk dan penjelasan mengenai Bahan hukum primer dan bahan hukum sekunder, seperti kamus KBBI, internet, majalah mingguan dan surat kabar yang digunakan dalam kajian penelitian hukum ini. Sepanjang memuat informasi yang relevan dengan objek.

\section{HASIL DAN PEMBAHASAN}

\section{Mekanisme Pelaksanaan Pemilu Ulang}

Sebagai sarana perwujudan kedaulatan rakyat untuk menghasilkan wakil rakyat dan pemerintah negara yang demokratis berdasarkan Pancasila dan UUD NRI 1945 dibentuklah Undang-undang Nomor 7 Tahun 2017 tentang Pemilihan Umum. Pemilu merupakan suatu cara menentukan wakil-wakil rakyat yang akan menjalankan pemerintahan (Anam, 2018), maka pelaksanaan Pemilu harus disertai kebebasan dalam arti tidak mendapat pengaruh maupun tekanan dari pihak manapun juga. Semakin banyak rakyat yang ikut Pemilu dapat dikatakan kadar demokrasi semakin tinggi dalam penyelenggaraan pemilu.

Pemilu ulang merupakan kegiatan pemilu yang mengalami cacat dalam pelaksanaannya, sedang pemilu yang ditunda bukan merupakan Pemilu ulang. Pemilu yang pelaksanaannya mengalami penundaan makan akan dilaksanakan Pemilu lanjutan atau Pemilu susulan. Pelaksanaan Pemilu ulang 
menyita waktu dan tenaga pemilih karena merupakan kerja ulang dari KPU, Bawaslu serta pihak terkait dalam panitia Pemilu setempat dan menambah beban operasionalnya.

Pelaksanaan pemilu ulang ditandai dengan adanya permasalahan dalam penyelenggaraan Pemilu. Masalah dalam Pemilu seperti yang disebutkan dalam Undang-Undang Pemilu terdiri dari pelanggaran Pemilu, sengketa Pemilu, Perselisihan hasil Pemilu dan tindak Pidana Pemilu.Pelanggaran Pemilu berdasarkan temuan pelanggaran pemilu dalam penyelenggaraannya dan laporan yang mengandung unsur pelanggaran pemilu. Pelapor yang melaporkan pelanggaran pemilu harus menyampaikan identitas secara tertulis. Pelanggaran pidana merupakan tindakan kriminal yang yang memberikan akibat terhadap pelaku berupa sanksi penjara cara atau denda yang sudah ditetapkan oleh undangundang. Perselisihan hasil Pemilu merupakan perselisihan pihak penyelenggara pemilu dengan peserta pemilu yang berkaitan terhadap perolehan suara hasil Pemilu secara nasional. Pemilu yang diselenggarakan dengan partisipasi masyarakat supaya tidak ada keberpihakan yang menguntungkan pihak-pihak tertentu dalam perolehan hasil suara. Sengketa proses pemilu adalah sebagai akibat dikeluarkannya keputusan KPU keputusan KPU provinsi dan keputusan KPU Kabupaten atau kota yang yang disengketakan peserta pemilu terhadap penyelenggara pemilu. Sengketa pemilu berkaitan dengan putusan KPU sebelum pemilu diselenggarakan.

Mekanisme pelanggaran pemilu, sengketa Pemilu, perselisihan hasil Pemilu dan tindak pidana pemilu berbeda-beda dalam penanganannya. Dalam hal yang memicu terjadinya kegagalan pemilu diselesaikan sesuai dengan mekanisme dari jenis permasalahannya namun pelaksanaan pemilu ulang hanya dapat diputus oleh mahkamah konstitusi mengenai perselisihan hasil Pemilu dan pelaksanaan pemilu ulang adalah upaya terakhir yang dikarenakan putusan penyelenggara Pemilu tidak dapat diterima oleh para pihak peserta pemilu yang mempengaruhi hasil suara akhir Pemilu. Bahwa berdasarkan pasal 24C ayat (1) UUD NRI 1945 MK Konstitusi berwenang mengadili pada tingkat pertama dan terakhir yang putusannya bersifat final, antara lain untuk memutus perselisihan tentang hasil Pemilu. Dalam menetapkan perolehan suara hasil peserta Pemilu anggota DPR, DPD,DPRD, dapat mengajukan permohonan pembatalan penetapan hasil perhitungan suara oleh KPU kepada MK, sedangkan dalam Penetapan suara hasil pemilu yang diperoleh Pasangan calon presiden dan wakil presiden mengajukan keberatan kepada MK setelah KPU menetapkan hasil Pemilu. Dalam pelaksanaan pemilu ulang akan menyita waktu dan tenaga pelaksana Pemilu dan peserta Pemilu untuk memungut suara dan menghitung suara seperti dalam pelaksanaan pemilu.

\section{Mekanisme Penggunaan APBN dalam Pelaksanaan Pemilu Ulang}

Keuangan negara adalah segala sesuatu yang berurusan dengan uang berkaitan dengan pendapatan dan pengeluaran. Dapat dikatakan bahwa yang dimaksud dengan uang atau keuangan negara dalam UUD NRI 1945 sebelum perubahan adalah APBN saja (Asshiddiqie, 2008).

Peran dan fungsi uang dalam pemilu sangat penting dalam mewujudkan pemilu yang berintegritas. Dalam pelaksanaan atau eksekusi anggaran biasanya menghabiskan anggaran sesuai perencanaan sehingga dalam pemilu ulang akan membutuhkan pembiayaan untuk melaksanakan pemungutan suara kembali dan penghitungan suara kembali di TPS yang cacat dalam pelaksanaan Pemilunya.

Pencapaian tujuan negara selalu terkait dengan keuangan negara sebagai bentuk pembiayaan terhadap penyelenggaraan pemerintahan negara. Tanpa keuangan negara, tujuan negara tidak dapat terselenggara, sehingga hanya berupa cita-cita hukum belaka. Untuk mendapat keuangan negara sebagai bentuk pembiayaan tujuan negara, harus tetap berada dalam bingkai hukum yang diperkenankan oleh UUD NRI 1945 (Saidi, 2011).

APBN yang menganggarkan Pemilu yang merupakan belanja Negara untuk mencapai tujuan demokrasi yang dalam pelaksanaannya mengalami cacat pelaksanaan Pemilu membutuhkan pembiayaan untuk menyelenggarakan Pemilu ulang. Pembiayaan dalam Pemilu ulang membutuhkan pendanaan yang sama seperti Pelaksanaan Pemilu sebelumnya di TPS yang mengalami cacat dalam pelaksanaan Pemilu. pembiayaan Pemilu ulang berkaitan dengan Anggaran Biaya Tambahan yang diajukan KPU.

Dalam pemberian dana APBN dalam pelaksanaan Pemilu, aktor yang terlibat dalam penyusunan perencanaan anggaran hanya KPU, DPR, dan Departemen Keuangan. KPU sebagai pihak yang mengusulkan anggaran, DPR sebagai lembaga anggaran, dan Departemen Keuangan/menteri keuangan merupakan bawahan presiden yang ditugaskan sebagai Direktorat jenderal Anggaran. Badan anggaran membahas bersama dalam pemerintah yang diwakili oleh menteri untuk menentukan pokok-pokok 
kebijakan fiskal secara umum dan prioritas anggaran untuk dijadikan acuan bagi setiap kementerian/lembaga dalam menyusun usulan anggaran.

Departemen keuangan memiliki kewenangan dalam peraturan Menteri Keuangan RI Nomor 206/PMK.02/2018 Tentang Tata Cara Revisi Anggaran Tahun Anggaran 2019 dalam Pasal 6. Direktorat Jenderal Anggaran berwenang memproses usul Revisi Anggaran bagian anggaran Kementerian/Lembaga dan Bagian Anggaran Bendahara Umum Negara yang memerlukan penelaahan dan revisi pengesahan untuk substansi tertentu, Direktorat Jenderal Perbendaharaan berwenang memproses usul Revisi Anggaran bagian anggaran Kementerian/Lembaga dan Bagian Anggaran Bendahara Umum Negara pengesahan tanpa memerlukan penelaahan.

KPU yang mengusulkan anggaran dan menerima anggaran dalam pengadaan perlengkapan pelaksanaan Pemilu ulang dan pendistribusian perlengkapan Pemilu ulang. Mekanisme perencanaan dan penggunaan serta Pelaksanaan Pemilu, perencanaan dibuat oleh sekjen KPU, sekjen melaporkan perkembangan pelaksanaan anggaran secara berkala kepada Pleno KPU. sekjen melakukan pengawasan terhadap seluruh pelaksanaan biaya Pemilu (Farhan \& Dkk, 2005). Pemilu ulang adalah bentuk pertanggungjawaban pelaksanaan Pemilu yang gagal.

\section{SIMPULAN AN SARAN}

\section{Simpulan}

Mekanisme pelaksanaan Pemilu ulang dalam hal pelanggaran pemilu, sengketa pemilu, perselisihan hasil pemilu, dan tindak pidana pemilu pemicu kegagalan pemilu. Mahkamah Konstitusi merupakan lembaga yang dapat mengeluarkan putusan mengenai Pemilu ulang. Putusan Mahkamah konstitusi hanya mencakup perselisihan hasil pemilu yang disengketakan oleh calon pasangan presiden dan anggota calon legislatif. Kemudian, peranan APBN dalam pelaksanaan Pemilu ulang Dalam hal pemberian dana APBN, KPU mengajukan anggaran biaya tambahan kepada lembaga anggaran yang terdiri dari DPR dan departemen keuangan merupakan Menteri Keuangan. Pengadaan dan pendistribusian pelaksanaan pemilu ulang dibiayai oleh APBN yang sudah direvisi berdasarkan pertimbangan departemen anggaran dan lembaga anggaran.

\section{Saran}

Melalui penelitian ini diharapkan kepada pemerintah untuk membangun hubungan yang harmonis antara KPU sebagai penyelenggara Pemilu, Bawaslu sebagai badan pengawas setiap tahapan Pemilu dan dan rakyat sebagai peserta Pemilu. Harmonisasi hubungan KPU, Bawaslu dan rakyat akan menjadi persoalan dalam kesuksesan Pelaksanaan Pemilu, terhindarnya dari pelaksanaan Pemilu ulang. Pemilu ulang di selenggarakan karena adanya pelanggaran pemilu dan perselisihan hasil Pemilu, dengan adanya proses tahapan penyelenggaran Pemilu ulang akan menambah anggaran yang dipergunakan untuk melakukan kegiatan yang sama. Kemudian, kepada KPU dalam menggunakan anggaran belanja harus sepadan dengan hasil yang sudah direncanakan sehingga tidak ada penggunaan anggaran tambahan dan dapat meminimalisir terjadinya kegagalan pelaksanaan Pemilu. hendaknya dalam menjalankan tugas dan fungsi harus sesuai dengan realita yang terdapat dalam undang-undang sehingga dapat tercapainya sistem demokrasi yang lebih baik. Selanjutnya, kepada masyarakat untuk mengikuti setiap aturan Undang-Undang dan setiap peraturan yang dibuat penyelenggara Pemilu untuk tercapainya pemilu yang jujur dan adil.

\section{DAFTAR PUSTAKA}

Anam, C. (2018). Pengaturan Alat Peraga Kampanye Dalam Pelaksanaan Pemilihan Kepala Daerah. JKMP (Jurnal Kebijakan Dan Manajemen Publik), 6(2), 113.

Asshiddiqie, J. (2008). Pokok-Pokok Hukum Tata Negara Indonesia Pasca Reformasi. Jakarta: PT. Bhuana Ilmu Komputer.

Bachtiar, M., Areros, W. A., \& Wullur, M. (2013). Implementasi Kebijakan Pengelolaan Keuangan Komisi Pemilihan Umum Provinsi Maluku Utara Melalui Keputusan KPU Nomor 506/Kpts/KPU/ TAHUN 2013. Politico: Jurnal Ilmu Politik, 10(4), 1-18.

Fajar, M., \& Dkk. (2010). Dualisme Penelitian Hukum Normatif dan Empiris. Yogyakarta: Pustaka Belajar.

Farhan, Y., \& Dkk. (2005). Merajut Pemilu Bersih. Jakarta: FITRA.

Lumapow, G. B. (2015). Analisis Kinerja Anggaran Belanja Pada Komisi Pemilihan Umum Provinsi Sulawesi Utara Tahun 2010-2014 (Politeknik Negeri Manado).

MD, M. M. (2000). Demokrasi Dan Konstitusi Di Indonesia. Jakarta: Rineka Cipta. 
Saidi, M. D. (2011). Hukum Keuangan Negara Edisi Revisi. Jakarta: Raja Grafindo Persada.

Savitri, K. A. A., Dewantara, M. A., Darmayanti, N. L. P. A., Dewi, K. Y. K., \& Sari, N. K. C. P. (2019). Analisis Faktor Penyebab Dan Akibat Dari Ketidaktepatan Waktu Penyusunan Anggaran Pendapatan Dan Belanja Daerah Kabupaten Buleleng Tahun 2017. Jurnal Ilmiah Akuntansi Dan Humanika, 9(1), 59-71.

Syamsurijal, C. A. (2019). Public Financial Analysis in the Preparation of Indonesia State Budget (APBN) 2018. Jurnal Perencanaan Pembangunan: The Indonesian Journal of Development Planning, 3(2), 203-224. 